\title{
Manganese for the Steel Industry
}

\author{
by F. W. Boulger and R. C. Buehl
}

$T^{2}$ HE steel industry currently uses about 700,000 tons of manganese annually. Technically feasible changes in composition probably would not lower the manganese content of finished steel by more than 5 pct.' Furthermore, it is too inexpensive and useful an element to justify even this much substitution. Therefore, the assurance of an adequate supply of manganese is of vital importance to the nation as well as to the steel industry.

Among other reasons, manganese is added to steel to improve its hot working properties. C. T. Anderson and coworkers of the Bureau of Mines made iron-carbon alloys containing only 0.004 pct $\mathrm{Mn}$ and tested them by twisting at hot rolling temperatures. They found it necessary to reduce the sulphur content to 0.002 pet to obtain good hot working properties. In these experiments, iron-carbon alloys with only 0.004 pct Mn could not be forged if the sulphur content exceeded 0.017 pct.

Even though there is no current shortage of manganese, the problem of making the United States relatively independent of foreign supplies is receiving attention. Studies are in progress on recovering manganese from low grade American ores and from open hearth slags. Slags are a potential source of manganese as Vignos ${ }^{2}$ showed in 1949. At present, more manganese goes to slag dumps than is received by steel plants as a ferroalloy.

R. C. Buehl and M. B. Royer described the Bureau of Mines pyrometallurgical process for recovering manganese from open hearth slag. This two-stage process involves producing spiegeleisen from open hearth slag in a blast furnace and then oxidizing it in a basic converter to obtain a high manganese slag.

A three-ton per day experimental blast furnace was operated by the Bureau of Mines during a period of several months. With this small experimental furnace, a spiegel containing 21 to 23 pct $\mathrm{Mn}$, 0.8 to 1.0 pet $S$, and 3 to 4 pet $P$ was produced from open hearth flush slag in a run covering several days. During this period, the manganese content of the slag varied from 3 to 4 pct. Tests also were run with a higher-iron flush slag, a mixture of flush and tap slags, and a manganiferous Maine ore. These raw materials resulted in spiegel of somewhat lower manganese content. Recoveries of around 60 pct were obtained in all the tests without the reuse of flue dust, which contained from 6 to 13 pct of the manganese charged. Coke consumption ranged from 3300 to $4100 \mathrm{lb}$ per ton of spiegel depending on the charge. High furnace temperatures and consequently slags of low manganese content were obtained by the use of high hot blast temperatures ranging from $1800^{\circ}$ to $2200^{\circ} \mathrm{F}$. Heat losses from a small furnace are proportionately very high, so from the standpoint of thermal balance a commercial furnace should theoretically be able to obtain comparable results at blast

F. W. BOULGER is Supervising Metallurgist, Battelle Memorial Institute, Columbus, and R. C. BUEHL is Chief, Ferrous Pyrometallurgy Section, Bureau of Mines, Pittsburgh. This session held on Tuesday afternoon, Feb. 19, 1952 at the AIME Annual Meeting, was sponsored jointly by the Extractive Metallurgy Div. and the Iron \& Steel Div. temperatures around $500^{\circ} \mathrm{F}$ lower. However, it has been demonstrated that good results could be obtained at lower temperatures.

In the second stage of the process, the spiegel containing 3 to 4 pct $\mathrm{P}$ was preferentially oxidized to give a manganese-rich slag low in phosphorus. Experiments in a basic lined, 500-1b converter indicated that single-stage treatments were unsatisfactory. Although manganese recoveries were good, the slags contained about 52 pct $\mathrm{Mn}, 10$ pct $\mathrm{Fe}$, and 0.8 pct $\mathrm{P}$. Therefore, this product did not have the manganese to iron and phosphorus ratios exceeding 8 and 250 to 1 , respectively, desired by ferroalloy producers.

Royer and Buehl found, however, that cyclic treatments would produce high-manganese slags with consistently low iron and phosphorus contents. The cycle recommended consists of: 1-Oxidizing the spiegel to 1 pct $\mathrm{Mn}$, and tapping the metal and retaining the slag; 2-Adding and partially blowing fresh spiegel, tapping the slag and retaining the metal, blowing the metal to 1 pct $\mathrm{Mn}$ and repeating the cycle. Such cyclic operations recovered about four fifths of the manganese from spiegel containing 3 to 4 pct $\mathrm{P}, 2$ to 3 pct $\mathrm{Si}$, and 20 pct $\mathrm{Mn}$. The slag product contained approximately 50 pet $\mathrm{Mn}, 2.0$ pct $\mathrm{Fe}, 0.08$ pct $\mathrm{P}$, and 22 pct $\mathrm{SiO}_{2}$. Unfortunately, there are objections to such high silica contents.

Laboratory tests indicated that using spiegel with lower silicon contents would produce a viscous slag containing about 13 pct $\mathrm{SiO}_{2}$. These slags trap about one tenth their weight of high-phosphorus metal shot. Magnetic separation of slags crushed to -20 mesh gave manganese recoveries of 98 pct. The final product contained about 60 pct $\mathrm{Mn}, 2.8$ pct Fe, 0.15 pct $\mathrm{P}$, and 15 pct $\mathrm{SiO}_{2}$. The composition of this material is closer to the current silica specifications for manganese ores. The Mn to phosphorus and $\mathrm{Mn}$. to iron ratios are satisfactory.

In any pyrometallurgical recovery process, which involves the reduction of manganese, a low ratio of the $\mathrm{MnO}$ content of the slag to the manganese in the metal is important in obtaining an acceptable manganese recovery from low grade raw materials.

Stukel and Cocubinsky studied the distribution of manganese between slag and metal using a graphite crucible in an induction furnace. Their results showed that at constant reaction temperature, $\mathrm{MnO}$ in the slag is proportional to the manganese content of the metal over the range normally found in basic pig iron ( 1 to 4 pct $\mathrm{Mn}$ ). The ratio of $\mathrm{MnO}$ in the slag to $\mathrm{Mn}$ in the metal decreased with increases of limesilica ratio, but the rate of decrease was rather small at basicities above 0.9. Magnesia can be substituted for lime up to $13 \mathrm{wt}$ pct without affecting the manganese distribution. The alumina content of the slag did not appear to affect the manganese distribution. The manganese recovery was enhanced by high limesilica ratios, high temperatures, and low slag volumes.

\section{References}

${ }^{1}$ American Iron and Steel Institute, Contributions to the Metallurgy of Steel, No. 3, October 1941.

${ }^{2}$ J. C. Vignos: How to Conserve Manganese. Journal of Metals, November 1949. 